rotavirus antigen ELISA (Rotaclone, NovoNordisk, Cambridge) (table). These results suggest that the positive reactions with the latex test were not specific for rotavirus antigen.

Latex agglutination tests are generally accepted as having a specificity approaching that of electron microscopy in the diagnosis of rotavirus infection. ${ }^{56}$ Laboratories that lack the facilities for electron microscopy can rely on this method as the sole test for making the diagnosis of rotavirus infection. A test which confuses haemorrhagic colitis with rotavirus infection could be falsely reassuring to the clinicians caring for the patient, especially when the result is available a day or two before the results of bacteriological investigations. In the light of our results we recommend that positive results with the RotaScreen latex test be confirmed by some other means.
We are currently looking at faecal samples collected from other patients with bloody diarrhoea to ascertain the incidence and nature of false positive reactions with this test.

1 Symonds J. Haemorrhagic colitis and Escherichia coli 0157-a pathogen unmasked. Br Med J 1988;296:875-6.

2 Karmali MA, Petric M, Lim C, et al. The association between idiopathic hemolytic uremic syndrome and infection by verotoxin-producing Escherichia coli. J Infect Dis tion by verotoxin-

3 Kaplan BS, Thompson PD, de Chadarevian J-P. The hemolytic uremic syndrome. Pediatr Clin North Am 1976;23:761-77.

4 WHO Scientific Working Group. Rotavirus and other viral diarrhoeas. Bull WHO 1980;58:183-98.

5 Sanekata T, Yoshida Y, Okada H. Detection of rotavirus in faeces by latex agglutination. J Immunol Methods 1981; 41:377-85.

6 Haikala OJ, Kokkonen JO, Leinonen MK, et al. Rapid detection of rotavirus in stool by latex agglutination: comparison with radioimmunoassay and electron microscopy and clinical evaluation of the test. J Med Virol 1983;11:91-7.

\title{
Detection of Borrelia burgdorferi in patients with Lyme disease by the polymerase chain reaction
}

\author{
E C Guy, G Stanek
}

\begin{abstract}
Borrelia burgdorferi, the causative agent of Lyme disease, was detected in patients' serum by DNA amplification using the polymerase chain reaction (PCR). B burgdorferi was pelleted from serum samples by centrifugation $(10000 \times g$ for 10 minutes) and lysed by treatment with ammonium hydroxide $\left(100^{\circ} \mathrm{C}\right.$ for 15 minutes). Two pairs of "nested" PCR primers complementary to the gene encoding a major outer surface protein (OSP A) of B burgdorferi were used in DNA amplification under standard PCR conditions (Perkin-Elmer Cetus). Two out of five patients with erythema migrans, the characteristic primary skin lesion associated with early Lyme disease, were positive by the PCR. This method could form the basis of a useful routine laboratory test in those cases of early Lyme disease where conventional serological testing commonly yields equivocal or false negative results.
\end{abstract}

The early diagnosis and treatment of Lyme disease can prevent progression to the later, more serious neurological and arthritic com- plications.' Unfortunately, the serodiagnosis of early Lyme disease is difficult due to the absence or barely detectable antibody response in the first weeks of infection. Furthermore, isolation of Borrelia burgdorferi, the causative agent of Lyme disease, from specimens is notoriously slow and difficult. ${ }^{2}$ We report a method, based on the polymerase chain reaction (PCR), for the direct detection of $B$ burgdorferi in the serum of patients manifesting the primary skin lesion of Lyme disease, erythema migrans.

\section{Methods}

Two pairs of "nested" PCR primers were constructed complementary to the gene encoding the $O s p-A$ protein of $B$ burgdorferi strain B31. ${ }^{3}$ Primer pair $1, O s p A-N 1$ (5'GAGCTTAAAGGAACTTCTGATAA-3') $O s p A-C 1$ (5'-GTATTGTTGTACTGTAATTGT-3'), and primer pair 2, OspA-N2 (5'ATGGATCTGGAGTACTTGAA-3') Osp $A$ C2 (5'-CTTAAAGTAACAGTTCCTTCT3'), correspond to nucleotide nos 334-356, 874-894, 362-381 and 693-713, respectively, of the $O s p A$ gene. The primers chosen are complementary to regions of the gene that are highly conserved between strains B31, ACA1, 
Summary of patient details

\begin{tabular}{lllll}
\hline Case No & $\begin{array}{l}\text { Age in } \\
\text { years }\end{array}$ & Sex & $\begin{array}{l}\text { Days blood sampled } \\
\text { after erythema migrans appeared }\end{array}$ & PCR \\
\hline 1 & 36 & F & 4 & - \\
2 & 58 & M & 13 & + \\
3 & 47 & F & 17 & - \\
4 & 64 & M & 25 & + \\
5 & 8 & M & 60 & - \\
\hline
\end{tabular}

and ZS7 (personal communication, S Bergstrom, University of Umea, Sweden). In addition to strains B31 (USA) and ACA1 (Swedish), strains DK1 and DK6 (Denmark) and a recent United Kingdom isolate of $B$ burgdorferi (kindly supplied by D J M Wright and S J Cutler, Charing Cross Hospital, London) were also amplified in the PCR using these primers. The related human pathogens Borrelia hermsii and Treponema pallidum, however, are not detected (E C Guy, unpublished data).

Serum $(100 \mu \mathrm{l})$ from five patients with a clinical diagnosis of erythema migrans confirmed by positive serology, previously stored at $-20^{\circ} \mathrm{C}$, was centrifuged at $10000 \times \mathrm{g}$ for five minutes. The supernatant was discarded and samples were incubated in the presence of $100 \mu \mathrm{l}$ ammonium hydroxide $(0.5 \mathrm{~mol} / \mathrm{l})$ at $100^{\circ} \mathrm{C}$ for five minutes in a sealed $0.5 \mathrm{ml}$ microfuge tube, followed by 10 minutes at $100^{\circ} \mathrm{C}$ with the tube open.

Each sample $(25 \mu \mathrm{l})$ was added to a standard PCR reaction mix (Amplitaq Kit; PerkinElmer Cetus) of final volume of $50 \mu \mathrm{l}$ containing $1.25 \mathrm{mmol} / 1 \mathrm{MgCl}_{2}$, and $1 \mu \mathrm{mol} / \mathrm{l}$ each of primers $O s p A-N 1$ and $O s p A-C 1$. PCR amplification was carried out for 40 cycles using a denaturing temperature of $94^{\circ} \mathrm{C}$, annealing temperature of $37^{\circ} \mathrm{C}$, and extension temperature of $72^{\circ} \mathrm{C}$. Each sample $(0.5 \mu \mathrm{l})$ was transferred to a second PCR reaction mix in which the starting primers were replaced with primers $O s p A-N 2$ and $O s p A-C 2$ and amplified for a further 25 cycles.

\section{Results}

Two of the five samples tested were found to be positive by the PCR. The patients' details are summarised in the table.

\section{Discussion}

The failure to detect $B$ burgdorferi in three of the five specimens tested could be a reflection of the transient spirochaetemia that has been suggested in early Lyme disease. ${ }^{4}$ In this preliminary study, however, only small samples of serum, originally stored for other purposes, were available. Therefore it is possible that a persistant but low level of spirochaetes in the blood could not be detected due to the $100 \mu \mathrm{l}$ volumes available for testing. Furthermore, in view of reports showing $B$ burgdorfer $i$ adherence to a number of eukaryotic cells types, ${ }^{5-7}$ it could be that a proportion of any spirochaetes present adehere to blood cells or platelets. We therefore propose to undertake a prospective study in which several samples of whole blood, taken from each subject over a period of time, are investigated.

1 Steere AC, Hutchinson GJ, Rahn DW, et al. Treatment of the early manifestations of Lyme disease. Ann Intern Med 1983;99:22-6.

2 Anonymous. Diagnosis of Lyme disease. [Editorial]. Lancet 1989;ii:198-9.

3 Bergstrom S, Bundoc VG, Barbour AG. Molecular analysis of the linear plasmid-encoded major outer surface proteins OspA and OspB of the Lyme disease spirochaete Borrelia burgdorferi. Mol Microbiol 1989;3:479-86.

4 Benach JL, Bosler EM, Hanrahan JP, et al. Spirochetes isolated from the blood of two patients with Lyme disease. N Engl J Med 1983;308:740-2.

5 Garcia-Monco JC, Fernandez-Villar B, Benach JL Adherence of the Lyme disease spirochete to glial cells and cells of glial origin. J Infect Dis 1989;160:497-506

6 Thomas DD, Comstock LE. Interaction of Lyme disease spirochetes with cultured eucaryotic cells. Infect Immun 1989;57:1324-6.

7 Szczepanski A, Furie MB, Benach JL, et al. Interaction between Borrelia burgdorferi and endothelium in vitro. $J$ Clin Invest 1990;85:1637-47. 